\title{
The Ukrainian Market of Ecological Tourism: The Current Trends and Development
}

\author{
V. O. Shvedun 1 ORCID: https://orcid.org/0000-0002-5170-4222. \\ V. Streltsov ${ }^{3}$ ORCID: https://orcid.org/0000-0002-6647-8678. \\ K. O. Husarov 1 ORCID: https://orcid.org/0000-0001-7509-8063. \\ S. I. Sysoieva2 ORCID: https://orcid.org/0000-0003-0790-0581. \\ R. M. Sheludko² ORCID: https://orcid.org/0000-0001-5287-2773. \\ S. V. Stankevych2 ORCID: https://orcid.org/0000-0002-8300-2591. \\ T. A. Butenko² ORCID: https://orcid.org/0000-0002-7723-0790. \\ T. G. Tkachenko² ORCID: https: //orcid.org/0000-0001-6794-0951. \\ A. O. Khmyrova1 ORCID: https: //orcid.org/0000-0002-0680-7505.
${ }^{1}$ National University of Civil Defence of Ukraine, 94 Chernyshevska Str. Kharkiv 61023, Ukraine
${ }^{2}$ V.V. Dokuchaev Kharkov National Agrarian University,
v. Dokuchaevske, Kharkiv region, 62483, Ukraine \\ 3 Pomeranian University, ul. Arcziszewskiego22A, Słupsk, 76200, Poland \\ E-mail: sergejstankevich1986@gmail.com. Tel.: +38-050-4000-985.
}

\section{Received 15.11.2019 Accepted 12.12.2019}

\begin{abstract}
The analysis of current trends in ecological tourism market of Ukraine and set of recommendations for its development under the state support are carried out in the research work. In particular, the analysis of the current condition of ecological tourism in Ukraine is carried out. The essence of this analysis is to assess the impact of the following factors on the gross domestic product of Ukraine during the past three years: number of foreign tourists in Ukraine, number of tourism objects, revenues from ecological tourism to local budgets, revenues from environmental tourism to the state budget, number of jobs in the field of ecological tourism and number of domestic tourists. The given analysis showed that the gross domestic product of Ukraine is practically unaffected by the following factors: number of foreign tourists in Ukraine, revenues from ecological tourism to local budgets and revenues from ecological tourism to the state budget. The recommendations on state support of ecological tourism development in Ukraine by introducing a set of models to increase the competitiveness of Ukrainian environmental regions, taking into account the level of influence of the studied factors on the gross domestic product, are developed. The given set of models includes a functional model of the tourism competitiveness of ecological region and a structural model for assessing of tourism competitiveness of ecological region.
\end{abstract}

Keywords: Ecological tourism; Tourist market; Influence factors; Competitiveness assessment; Correlation analysis; Ecological region

\section{Introduction}

Gradual rising of the rate and improving the efficiency of the ecological tourist industry enterprises and the industry formation as one of the leading sectors of the national economy are restrained by the unsettled questions. Solving of these questions demands the state regulation and support of the executive bodies.

Nowadays the main obstacle in the development of ecological tourism at the social level is the lack of the attention and support from the politicians and public authorities. When tourism is not considered, its revenues will not be defined, there will no careful planning and, consequently, there will no development. As soon as there are a deep interest at the legislative level, and the combination of efforts to raise the status of ecological tourism industry to a higher level, not only in the form of the declarations, but also by the concrete measures for establishing and maintaining the economic relations, then marketing will begin to operate effectively in the field of ecological tourism, since then one can rely on the visible results.

Among the key issues to be solved in the nearest future are the optimization of the interaction of ecological tourism and culture both at the level of central and local authorities. Cultural heritage, museums, and theaters in most countries of the world are an extremely important factor in attracting tourists, generating the international and local tourist flows. As a result the transport, catering, hotels, and local industry will get their clients. The coordination of the strategic development of the cultural sphere and ecological tourism in the provinces should lead to closer cooperation between the local authorities and real business in solving the specific tasks for preservation of the cultural heritage. It should also promote the activities of the museums and national reserves direct toward the work of the best managers under market conditions and coordinate the activities with the subjects of ecological tourist industry. 
The problems of tourism development especially concerning ecological one have been in the centre of attention of many scientists for several decades.

For example, S. Abram, J. Waldren, \& D.V.L. Macleod think that tourism is a major global industry forecast to continue its dramatic growth well into the twenty-first century is often cited as a rationale for its analysis (Abram, Waldren, \& Macleod, 1997).

Author N.F. Alberts describes various strategies, which are used in tourism, in particular, in ecological one, both for promotion of separate tourist products, and for development of tourism industry in general within global scale (Alberts, 2004).

It is necessary to analyze the point of view of J.A. Bennett, who thinks that ecological tourism development may not bring lasting economic benefits to a country; it might trigger inflation and bring environmental degradation and economic dependency (Bennet, 2000). The aim of work of M. Risteski is to present the importance of the contemporary changes in tourism, in particular, concerning ecological one, which requires adaptation of all participants in the creation of ecological tourism offer in given destinations (Risteski, 2012). The French author E. Gormsen also made the contribution to the study of spatial and temporal development of ecological tourism (Gormsen, 1981). At the example of the seaside resorts development his model illustrates the connection between the evolution of the tourist destination and changes in the social structure of the holiday-makers, as well as between the number and variety of the accommodation infrastructure. At the same time some political and managerial aspects of the theory and practice of the state regulation in the field of ecological tourism require further reflection in the scientific literature. We mean the peculiarities of promoting the national ecological tourist product into the world market, the ways of attracting the foreign investments into ecological tourist industry, the possibility of supporting ecological tourism development in the Ukrainian regions by the local government bodies, and so on.

Taking into account the urgency of the chosen topic of the study, the goal of the current work is analysis of the current trends in market of ecological tourism of Ukraine and working out of offers on its development under the state support. This is necessary in order to determine the opportunities and create the favorable conditions for the development of market of ecological tourism and brining Ukraine into the world market of ecological tourist services.

\section{Material and Methods}

The correlation analysis is used for identification of dependence of the gross domestic product of Ukraine from the following factors concerning ecological tourism:

(1) Quantity of foreign tourists in Ukraine;

(2) Quantity of subjects of tourist activity;

(3) Receipts to local budgets from ecological tourism;

(4) Receipts to the state budget from ecological tourism;

(5) Quantity of jobs in ecological tourism;

(6) Quantity of internal tourists.

is used in the article.

Correlation reflects interdependence of two or several random variables. Its essence is that there is a natural change (reduction or increase) of one variable at change of value of another variable(s).

When calculating correlations scientists and practicians usually try to define whether there is statistically reliable communication between two or several variables in one or several selections.

It is important to understand that the correlation dependence reflects only interrelation between variables and does not describe relationships of cause and effect. Correlation communication only describes the coherence of these parameters, and there is no opportunity to observe the received correlations in this concrete selection or in other selection

Correlation coefficient is the basic correlation indicator. The coefficient of correlation characterizes the figure reflecting degree of interrelation of two variables. It can vary from-1 (negative correlation) up to 1 (positive correlation). If the coefficient of correlation is equal 0 , it means lack of correlation communications between variables. And if the coefficient of correlation is closer to 1 (or- 1 ) then the correlation is strong and if it is closer to 0 , then the correlation is weak.

The correlation coefficient is calculated as follows:

$$
R=\sqrt{R^{2}}
$$

Where $R$ - correlation coefficient; $R^{2}$ - Determination coefficient.

In particular, determination coefficient is calculated in such a way:

$$
R^{2}=\frac{\sum(Y-\bar{y})^{2}}{\sum(y-\bar{y})^{2}},
$$

$Y$ - New value of a resultant factor; Y- Existing value of a resultant factor; ${ }^{\bar{y}}$ - Average value of a resultant factor.

The increase (or reduction) of values of one variable leads to natural increase (or reduction) of other variable at positive correlation. The increase (or reduction) of values of one variable leads to natural reduction (or increase) of other variable at negative correlation.

\section{Results and Discussion}

\section{The analysis of the current condition of ecological tourism in Ukraine}

Tourism is a highly profitable branch of the national economy in many countries of the world. This is convincingly evidenced by the profitability indices of ecological tourist industry. For example in Spain ecological tourism brings 17 billion dollars of profit each year (it constitutes 30\% of the country's annual exports); in Italy it brings $11 \%$, and in Denmark and Austria - $8 \%$ respectively (Riseski, 2012). It is clear that today the indicators of the economic efficiency of Ukrainian ecological tourism differ from the foreign ones. However, it should be noted that in some regions of Ukraine ecological tourism as an economic branch is quite developed.

Therefore it is offered to estimate the influence of ecological tourism on gross domestic product of Ukraine in the given work. In particular, it is offered to estimate the dynamics of change of key factors of ecological tourism development in Ukraine within the 
last 3 years. The first key factor is dynamics of change of number of foreign tourists in Ukraine (Figure 1) (Ministry of Economic, 2019).

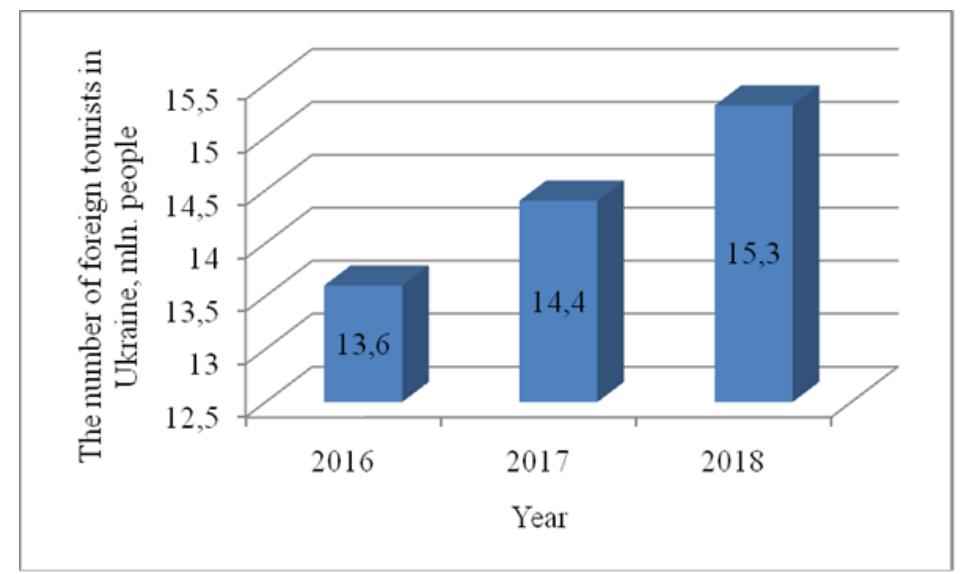

Figure 1. The dynamics of change of number of foreign tourists in Ukraine, mil. People.

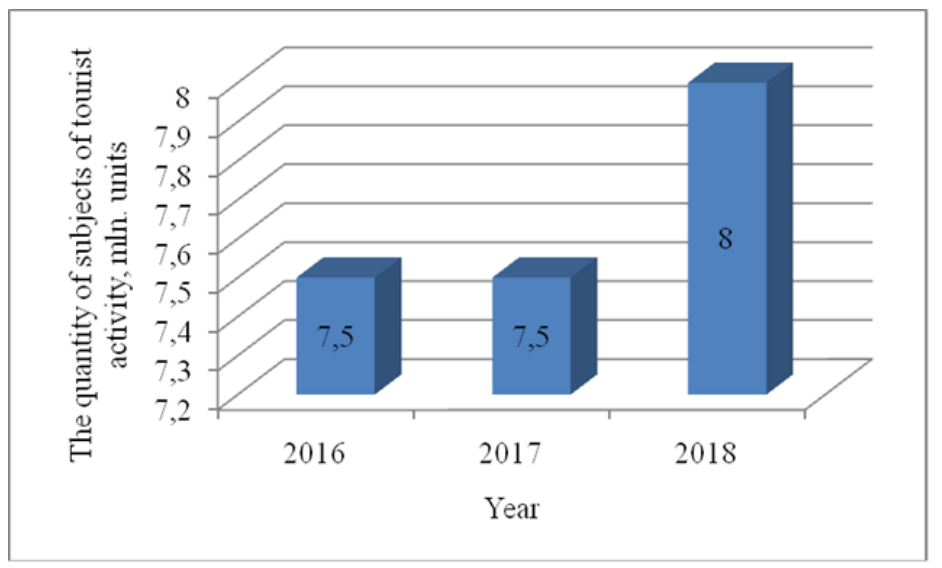

Figure 2. The dynamics of change of quantity of subjects of tourist activity, mil. Units.

Having carried out the analysis of change of number of foreign tourists in Ukraine, it is possible to see that it increased during 20162018. In particular, it increased by $6 \%$ in 2017 in comparison with 2016 . As for 2018, this indicator also increased by $6 \%$ in comparison with 2017. The dynamics of change of quantity of subjects of tourist activity during 2016-2018 is showed on Figure 2 (Ministry of Economic, 2019). It is possible to see from Figure 2 that the quantity of subjects of tourist activity remained invariable during 2016-2017. In 2018 quantity of subjects of tourist activity increased up to 8 mil. units that is a positive tendency. The dynamics of change of receipts to local budgets from ecological tourism during 2016-2018 is showed on Figure 3 (Ministry of Economic, 2019). It is possible to see from Figure 3 that the receipts to local budgets from ecological tourism increased by $29 \%$ in 2017 in comparison with 2016. As for 2018, this indicator also increased by $10 \%$ in comparison with 2017. But the growth rate of this indicator slowed down.

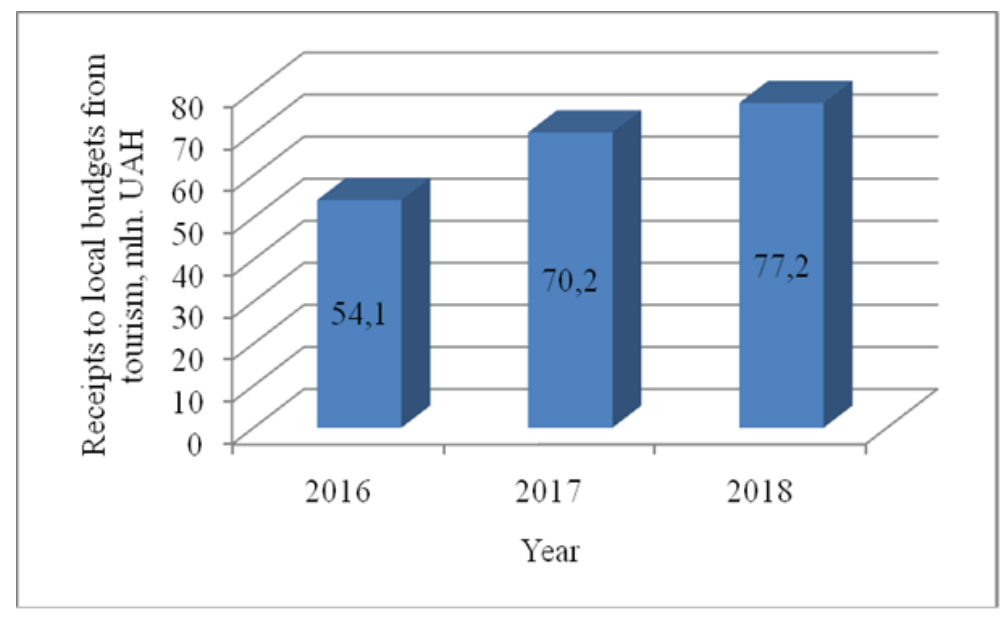

Figure 3. The dynamics of change of receipts to local budgets from ecological tourism, mil. UAH. 


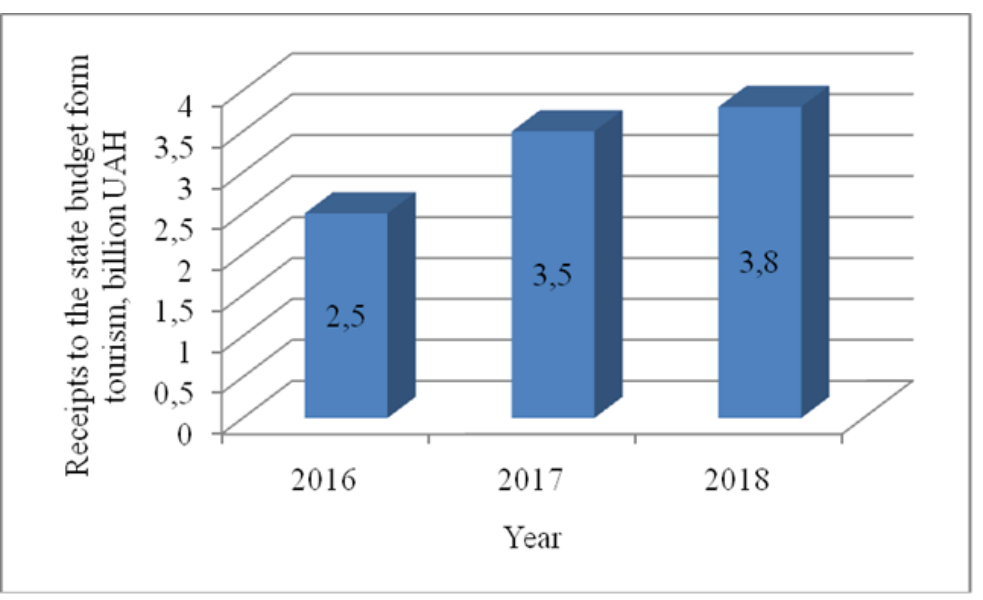

Figure 4. The dynamics of change of receipts to the state budget from ecological tourism, billion UAH.

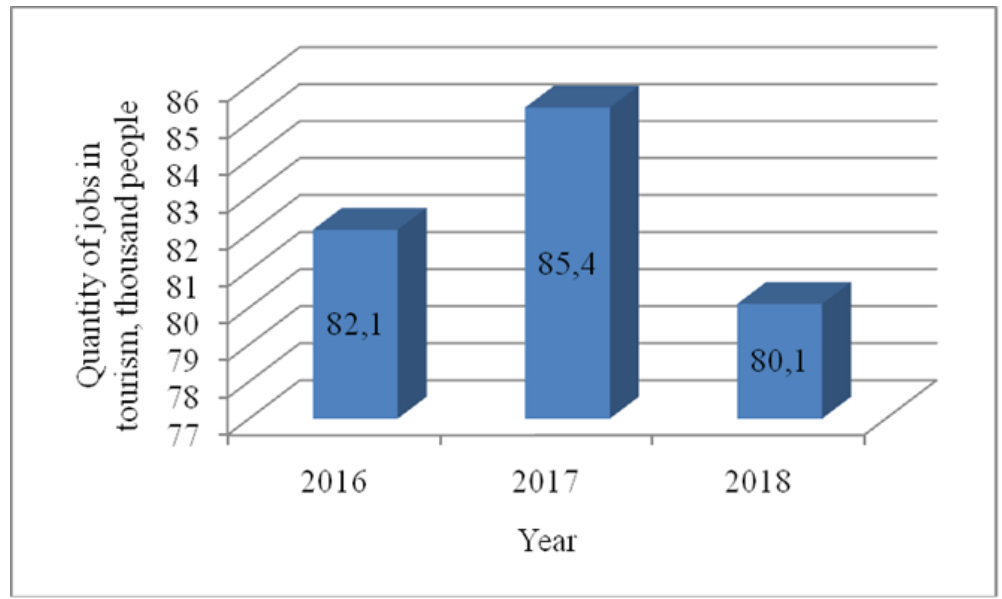

Figure 5. The dynamics of change of quantity of jobs in ecological tourism, thousand people.

The dynamics of change of receipts to the state budget from ecological tourism during 2016-2018 is showed on Figure 4 (Ministry of Economic, 2019). It is possible to see from Figure 4 that the receipts to the state budget from ecological tourism increased by $40 \%$ in 2017 in comparison with 2016. As for 2018, this indicator increased by $9 \%$ in comparison with 2017. But the growth rate of this indicator slowed down too. The dynamics of change of quantity of jobs in ecological tourism during 2016-2018 is showed on Figure 5 (Ministry of Economic Development and Trade of Ukraine, 2019). The data in Figure 5 demonstrate that the quantity of jobs in ecological tourism grew by 3.3 thousand people in 2017 in comparison with 2016 . But the quantity of jobs in ecological tourism decreased by 5.3 thousand people in 2018 in comparison with 2017. At the same time the given situation in 2018 contradicts the fact that the quantity of subjects of tourist activity significantly increased in 2018.

The dynamics of change of quantity of internal tourists during 2016-2018 is showed on Figure 6 (Ministry of Economic, 2019). As for the dynamics of change of quantity of internal tourists during 2016-2018, this quantity increased in 23.4 thousand people in 2017 in comparison with 2016 and in 123 thousand people in 2018 in comparison with 2017.

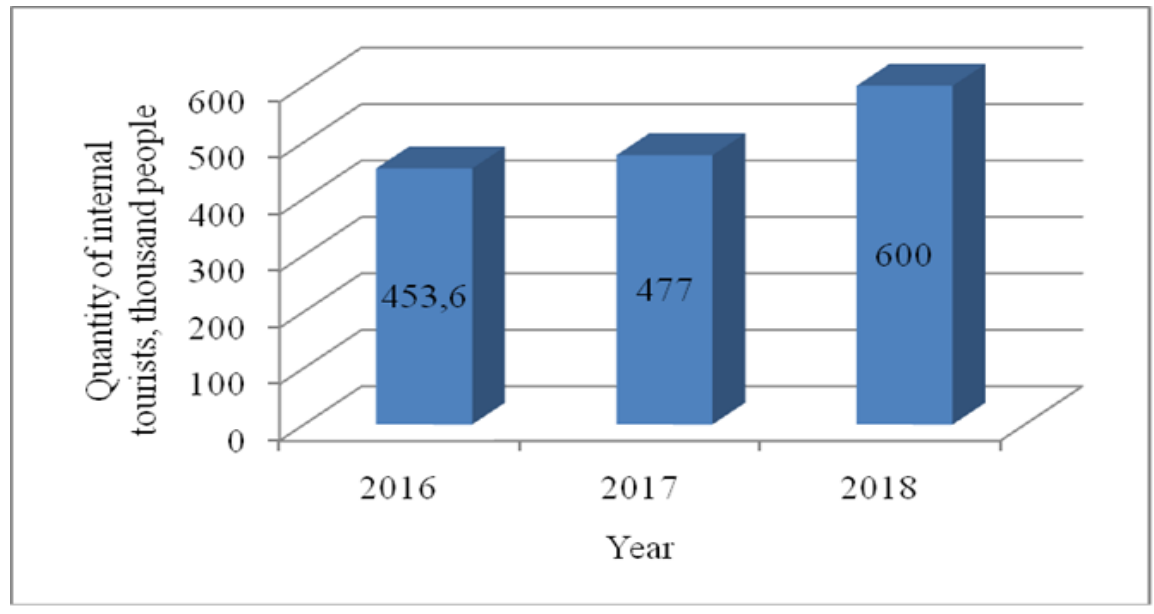

Figure 6. The dynamics of change of quantity of internal tourists, thousand people. 
It had to stimulate the growth of the receipts to the state budget from ecological tourism and the quantity of jobs in ecological tourism, however, these indicators decreased.

\section{Assessment of influence of factors of ecological tourist market on gross domestic product of Ukraine.}

Considering a set of the factors influencing development of ecological tourist market in Ukraine, it is expedient to define what of the analyzed indicators had the greatest impact on gross domestic product of Ukraine during 2016-2018. This analysis needs to be carried out for the purpose of identification of indicators which should be paid by special attention in the course of improvement of state policy of ecological tourism development. The initial data for the given analysis carrying out are shown in Table 1 (Ministry of Economic, 2019). The results of assessment of influence of factors of ecological tourist market on gross domestic product of Ukraine with the help of correlation analysis are shown in Table 2.

Table 1. The initial data for assessment of influence of factors of ecological tourist market on gross domestic product of Ukraine.

\begin{tabular}{|c|c|c|c|c|c|c|c|}
\hline Year & $\begin{array}{l}\text { Gross } \\
\text { domestic } \\
\text { product of } \\
\text { Ukraine, mil. } \\
\text { UAH } \\
\text { (Column 1) }\end{array}$ & $\begin{array}{l}\text { Quantity of } \\
\text { foreign } \\
\text { tourists in } \\
\text { Ukraine, } \\
\text { mil. people } \\
\text { (Column 2) }\end{array}$ & $\begin{array}{l}\text { Quantity } \\
\text { of } \\
\text { subjects } \\
\text { of tourist } \\
\text { activity, } \\
\text { mil. units } \\
\text { (Column } \\
\text { 3) }\end{array}$ & $\begin{array}{l}\text { Receipts to } \\
\text { local } \\
\text { budgets } \\
\text { from } \\
\text { ecological } \\
\text { tourism, } \\
\text { mil. UAH } \\
\text { (Column 4) }\end{array}$ & $\begin{array}{l}\text { Receipts to } \\
\text { the state } \\
\text { budget } \\
\text { from } \\
\text { ecological } \\
\text { tourism, } \\
\text { billion UAH } \\
\text { (Column 6) }\end{array}$ & $\begin{array}{l}\text { Quantity } \\
\text { of jobs in } \\
\text { ecological } \\
\text { tourism, } \\
\text { thousand } \\
\text { people } \\
\text { (Column } \\
\text { 6) }\end{array}$ & $\begin{array}{l}\text { Quantity } \\
\text { of internal } \\
\text { tourists, } \\
\text { thousand } \\
\text { people } \\
\text { (Column } \\
\text { 7) }\end{array}$ \\
\hline 2016 & 2383182 & 13,6 & 7,5 & 54,1 & 2,5 & 82,1 & 453,6 \\
\hline 2017 & 2982920 & 14,4 & 7,5 & 70,2 & 3,5 & 85,4 & 477 \\
\hline 2018 & 3558706 & 15,3 & 8 & 77,2 & 3,8 & 80,1 & 600 \\
\hline
\end{tabular}

Table 2. The results of assessment of influence of factors o ecological tourist market on gross domestic product of Ukraine with the help of correlation analysis.

\begin{tabular}{llllllll}
\hline & Column 1 & Column 2 & Column 3 & Column 4 & Column 5 & Column 6 & Column 7 \\
Column 1 & 1 & & & & & & \\
Column 2 & 0,99895539 & 1 & & & & & \\
Column 3 & 0,86008397 & 0,882498 & 1 & & & & \\
Column 4 & 0,97763869 & 0,967008 & 0,733571 & 1 & & \\
Column 5 & 0,95834509 & 0,944293 & 0,678551 & 0,996977 & 1 & \\
Column 6 & $-0,3626936$ & $-0,4049$ & $-0,78736$ & $-0,15861$ & $-0,08142$ & 1 & \\
Column 7 & 0,92640864 & 0,942646 & 0,988872 & 0,826514 & 0,78028 & $-0,68688$ & 1 \\
\hline
\end{tabular}

It is possible to see from Table 2 that the gross domestic product of Ukraine is hardly influenced by the following factors:

(1) Quantity of foreign tourists in Ukraine $\left(R^{2} \approx 1\right)$;

(2) Receipts to local budgets from ecological tourism ( $\left.R^{2} \approx 0.98\right)$;

(3) Receipts to the state budget from ecological tourism ( $R^{2} \approx 0.96$ ).

Respectively, state support in stimulation of development of the specified factors is necessary.

\section{The recommendations on the state support of development of ecological tourism in Ukraine}

The urgency of ecological tourism development in Ukrainian regions causes the profits from which can be a significant supplement to the state budget of Ukraine.

Accordingly, it is necessary to highlight the main principles of building of a tourist model for Ukrainian ecological tourist regions' development (Figure 7).

Improvement of non-productive sector, especially in the mountainous part of the region is an important element of building of the competitive mechanism of ecological tourist region development. The key to the successful development of this industry is the compliance with the norms of the environmental protection, preservation and restoration of the historical and cultural heritage. Creation of the conditions necessary for the development of these industries will ensure the rise of their socio-economic level that should be determined by the needs and interests of the business entities located in the region as well as by the needs and interests of the local population. If to accept the above given factors it can be possible to identify the main counterparts of ecological regions' touristic competitiveness. 13 main counterparts of ecological regions' tourist competitiveness are schematically given on Figure 8 . We propose to consider a functional model for assessing the touristic competitiveness of Ukrainian ecological regions (Figure 9). In order to confirm the validity of this choice we present a structural model of ecological regions' tourist competitiveness assessment which has been developed by us (Figure 10).

So, taking into account the fact that the tourist industry plays a significant role in the socio-economic development of Ukraine, the level of the state interest in stimulating the further development of ecological tourist activity is also increasing.

It is also necessary to emphasize the fact that the availability of transport, favorable economic and geographical position, and the widespread intercourse are an undoubted stimulating factor for the active development of business and educational tourism. 


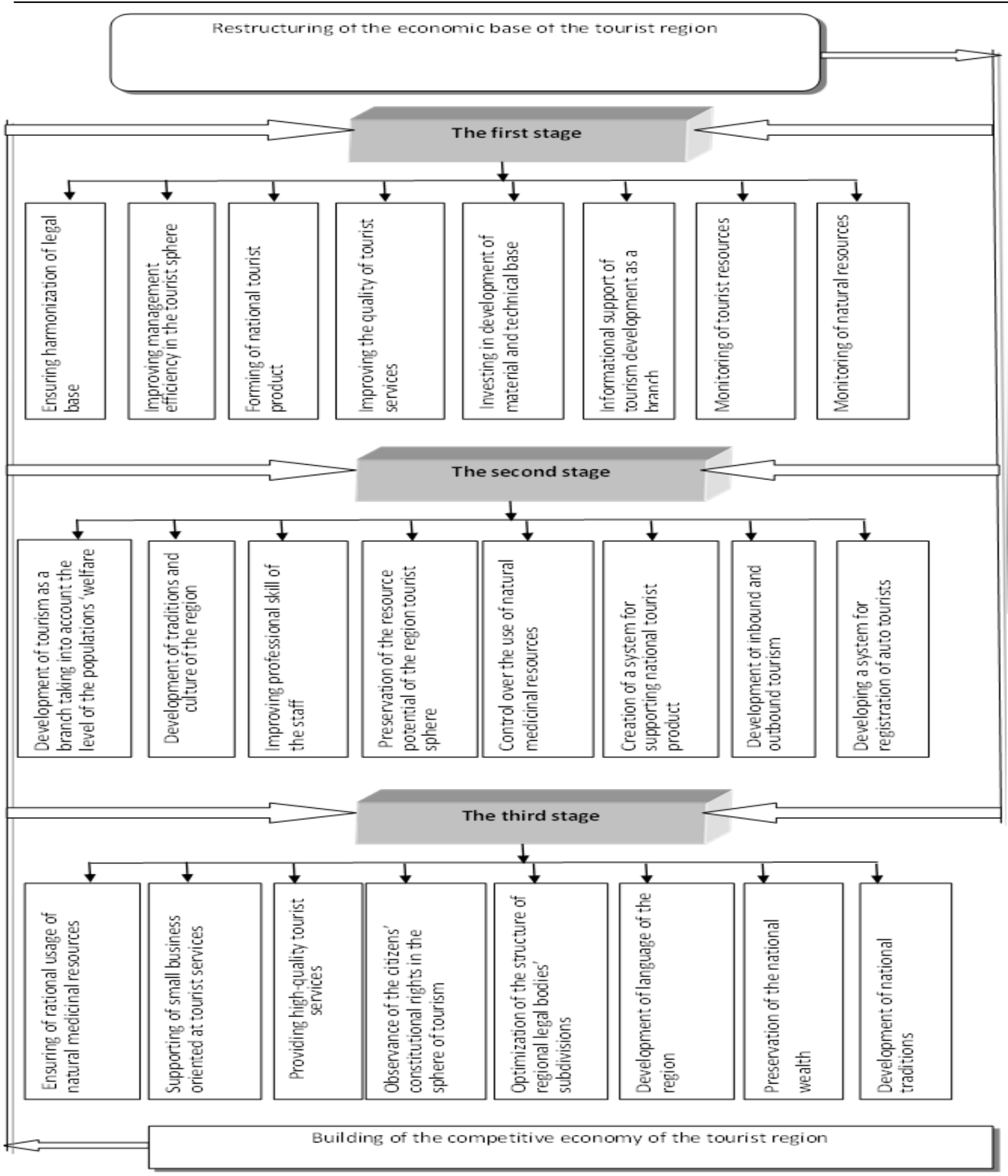

Figure 7. The stages of achieving of competitiveness of Ukrainian ecological tourist regions.

Investigating the problem of the regional ecological tourism competitiveness, it is worth pointing out that today ecological tourism as a branch of the service industry is organically included in the sphere of production at the regional level. In its turn the role of the services industry is also determined by the necessity to reorganize the management system of the tourist enterprises and create new jobs.

\section{Discussion}

It should be noted that the model developed in article, which gives an opportunity to make the dependence assessment of the gross domestic product of Ukraine from a set of factors of ecological tourist market, allows estimating deeply the specified dependence and also the interdependence of the influencing factors. It is noted in the work that Ukrainian gross domestic product highly depend on qquantity of foreign tourists in Ukraine, rreceipts to local budgets from ecological tourism and receipts to the state budget from tourism. 


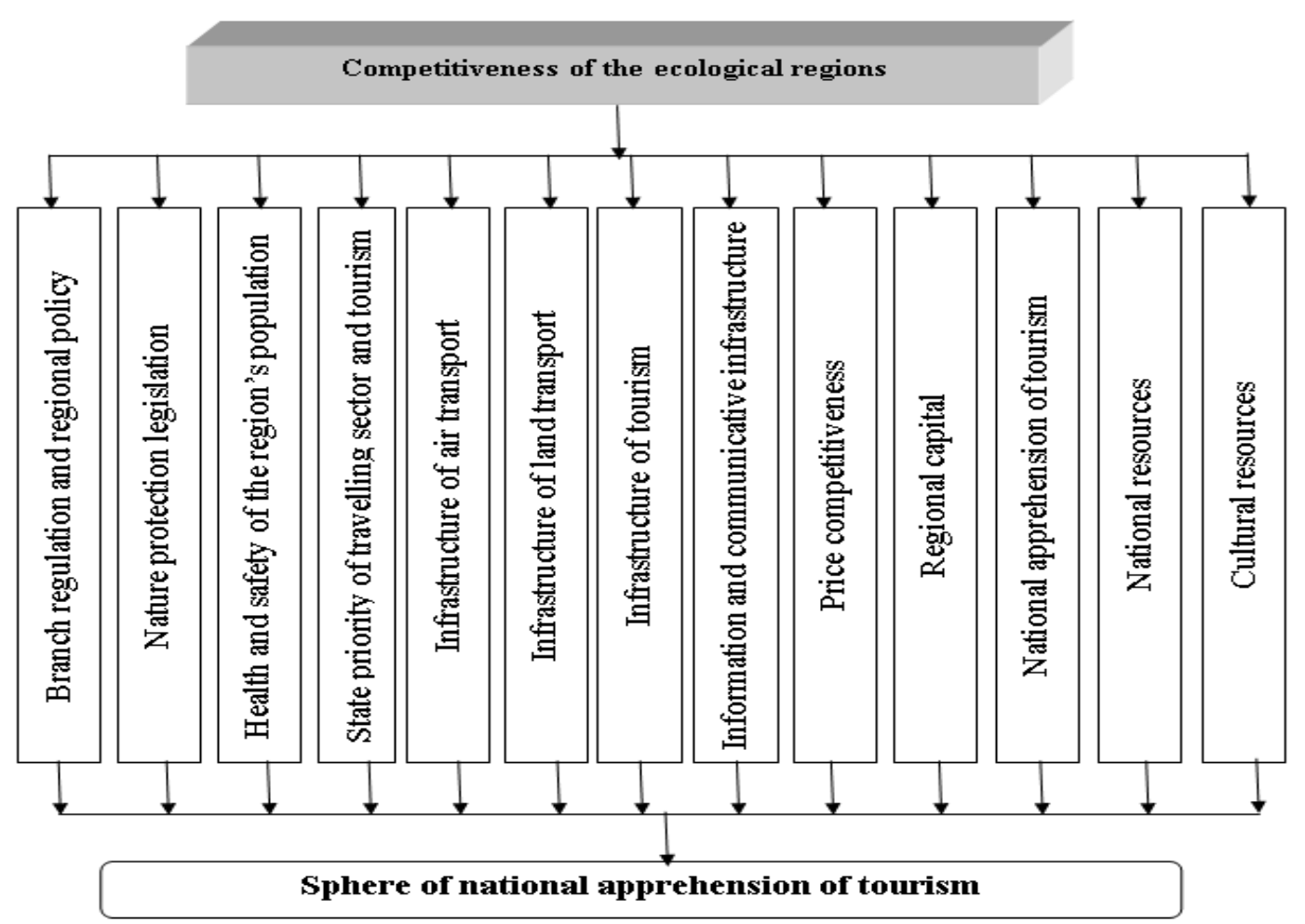

Figure 8. The main counterparts of ecological regions' tourist competitiveness.

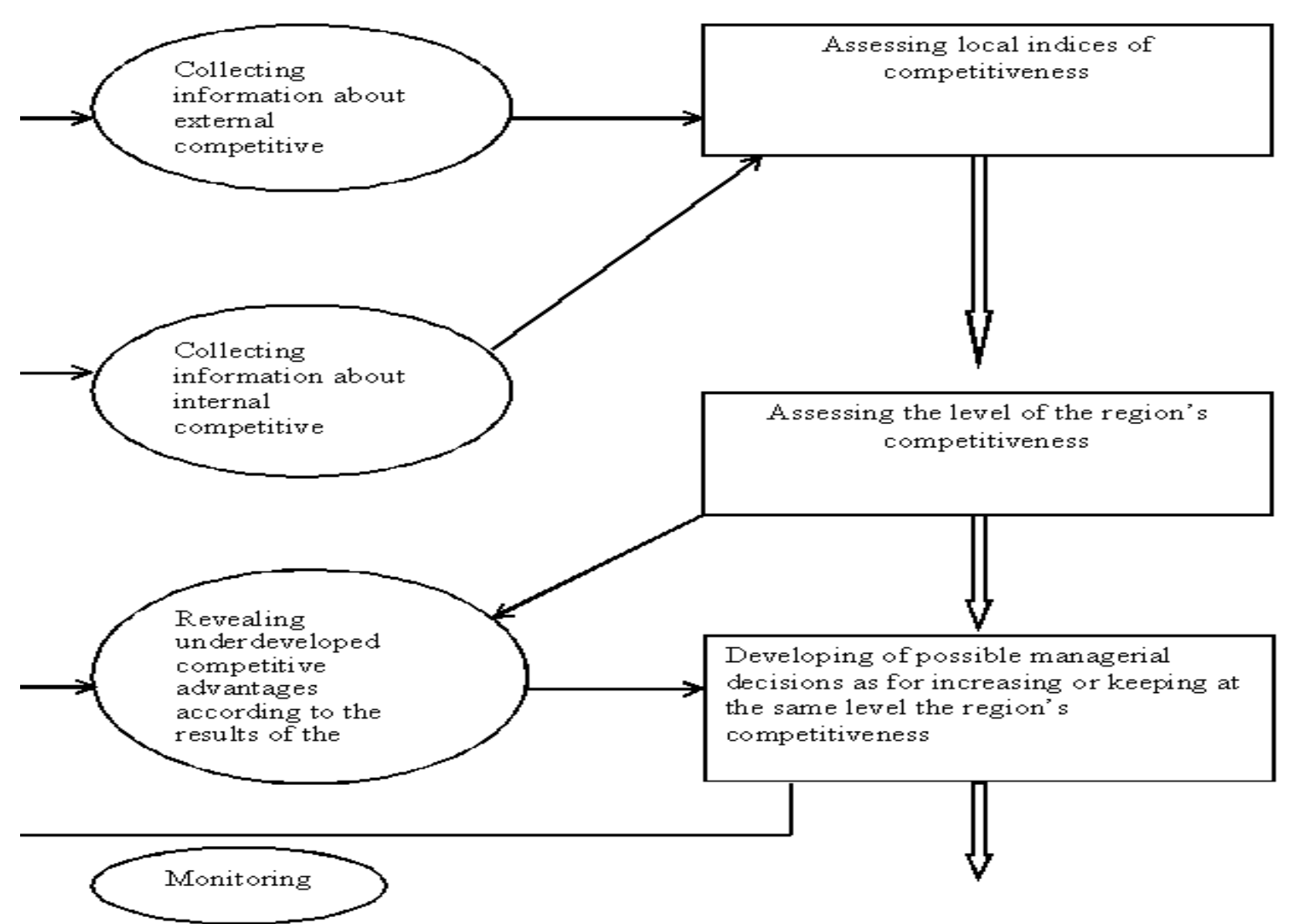

Figure 9. The functional model of ecological region's tourist competitiveness. 


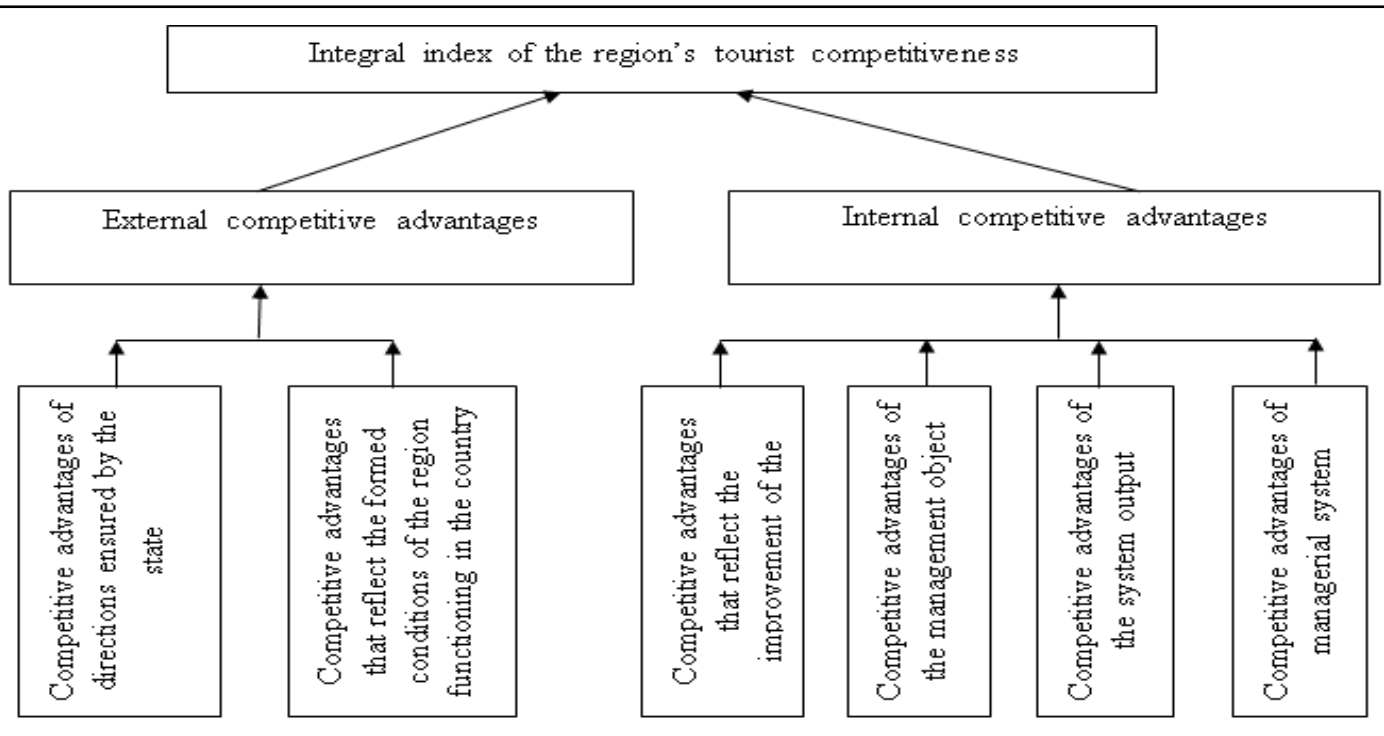

Figure 10. The structural model of ecological region's tourist competitiveness assessment.

However, it is recommended to prove and comment the interdependence of the influencing factors more detail. In particular, of the quantity of foreign tourists in Ukraine increases, the receipts to local budgets from ecological tourism and the receipts to the state budget from ecological tourism will increase too. At the same time narrowness of communication between these factors is very high ( $R^{2} \approx 0.98$ and $R^{2} \approx 0.96$ respectively).

The given profound analysis of interdependence of the influencing factors will allow developing of a complex of specific recommendations for improvement of state regulation of ecological tourist sphere functioning processes taking into account the features of factors' interaction.

\section{Conclusion}

Thus, as a result of the study the following conclusions were obtained. An analysis of Ukrainian tourist market shows that ecological tourism development in Ukraine is only at an initial stage. An increase in the inbound and outbound tourist flows is now slowing down due to a number of the negative factors which include the insufficient development of the tourist infrastructure, undeveloped regulatory and legal base, the economic and political instability in the country, the limited range of the services offered, lack of a comprehensive vision of the country as a promising tourist destination, the imperfect advertising of Ukrainian ecological tourist centers abroad and others. So it is necessary to take into account the maximum possible number of these factors in the perspective studies. The conducted research allowed revealing of the factors of Ukrainian tourist industry development, in particular, ecological one, which have the strongest impact on gross domestic product. Respectively, the complex of models of improving of competitiveness of Ukrainian regions taking into account the level of influence of the specified factors on the gross domestic product was developed. The results received in work will allow improving significantly the level of state regulation of ecological tourist sphere in Ukraine that will increase the general level of its economic development and competitiveness at the world level.

\section{References}

Abram, S. Waldren, J., Macleod, D.V.L. (1997). Tourists and tourism, Identifying with people and places, New York, Oxford University Press, UK.

Alberts, N. F. (2004). Strategic Tourism Management (TBE 971), University of Pretoria, Unpublished Class Notes.

Ashworth, G. J., Tunbridge, J. E. (1990). The tourist, Belhaven, Historic City Publishers.

Ballantynea, R., Packera, J., Axelsena M. (2009). Trends in tourism research. Australia Annals of Tourism Research,36(1), 149-152.

Bennett, J. A. (2000). Economic, physical and social consequences of tourism. Pretoria, Van Schaik.

Cooper, C., Fletcher, J., Gilbert, D., Wanhill, S. (1993). Tourism principles and practice, Harlow, Pearson, UK.

Gormsen, E. (1981). Le tourisme international, un nouveau 'front pionnier' dans les pays tropicaux. Traveaux \& Mémoires, Institut des Hautes Etudes de l'Amérique Latine, 34, 329-345.

Jennings, G. (2001). Tourism research, Chichester, John Wiley and Sons, NY, USA.

Kozal, M., Louisa, A. (2006). Progress in Tourism Marketing, Amsterdam, Elsevier, USA.

Ministry of Economic Development and Trade of Ukraine (Official Website) (2019). http://www.me.gov.ua/?lang=en-GB Accessed 18 May 2019.

Pender, L., Sharpley, R. (2005). The management of tourism, London, SAGE Publications Ltd, USA.

Risteski, M. (2012). Spatial planning and sustainable tourism as basis for developing competitive tourist destinations. Procedia-Social and Behavioral Sciences, 44, 375-386.

Robson, C. (1997) From shareholders to stakeholders, critical issues for tourism market, Tourism Management, 17(7), 533-540.

Rogerson, C. M. (2004). Tourism and development issues in contemporary South Africa, Pretoria, Africa Institute of South Africa. Smith, W. L. (2006). Experiential tourism around the world and at home: definitions and standards. International Journal of Services and Standards (IJSS), 2(1), 1-14.

\section{Citation:}

Shvedun, V. O., Streltsov, V., Husarov, K. O., Sysoieva, S. I., Sheludko, R. M., Stankevych, S. V., Butenko, T. A., T. G. Tkachenko A. O.

Khmyrova. (2019). The ukrainian market of ecological tourism: the current trends and development. Ukrainian Journal of Ecology, 9(4), 598-605. 